\title{
Vermicomposting in Pakistan: Current Scenario and Future Prospectives
}

ISSN: 2637-7659

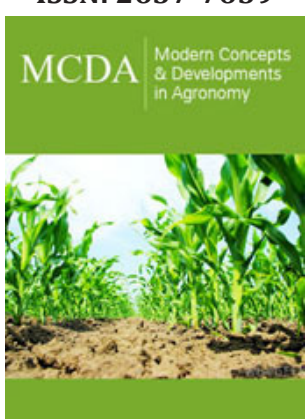

*Corresponding author: Zubair Aslam, University of Agriculture Faisalabad, Faisalabad, Pakistan

Submission: 眥 January 16, 2020

Published: 僵March 13, 2020

Volume 6 - Issue 1

How to cite this article: Sami-ur-Rehman, Zubair Aslam, Korkmaz BELLITÜRK, Ali Ahmad, Mehwish Nadeem, Muhammad Waqas. Vermicomposting in Pakistan: Current Scenario and Future Prospectives. Mod Concep Dev Agrono.6(1) MCDA.000629.2020.

DOI: 10.31031/MCDA.2020.06.000629

Copyright@ Zubair Aslam, This article is distributed under the terms of the Creative Commons Attribution 4.0 International License, which permits unrestricted use and redistribution provided that the original author and source are credited.

\author{
Sami-ur-Rehman ${ }^{1}$, Zubair Aslam ${ }^{1 *}$, Korkmaz BELLíTüRK ${ }^{2}$, Ali Ahmad ${ }^{1}$, \\ Mehwish Nadeem ${ }^{1}$ and Muhammad Waqas ${ }^{1}$ \\ ${ }^{1}$ University of Agriculture Faisalabad, Pakistan \\ ${ }^{2}$ Department of Soil Science and Plant Nutrition, Tekirdag Namık Kemal University, Turkey
}

\begin{abstract}
Crop residues and waste management are serious issues in Pakistan. Burning of crops residue leads to environmental pollution such as smog. Vermicomposting is the best technique to manage wastes and crop residues and convert them into nutrient-rich organic fertilizer. Vermicompost contains macro \& micronutrients, growth regulators and microbes that help in the solubilization of zinc and phosphorus. Future perspective of vermicomposting in Pakistan is the production of vermicompost, less reliant on chemical fertilizers and moving towards organic farming.
\end{abstract}

\section{Introduction}

Agriculture is a backbone of Pakistan's economy. Total geographical area of Pakistan is 79.61 million hectares. Out of this, 22 million hectares is under cropped area. Agriculture accounts for $24 \%$ of growth domestic product (GDP) of Pakistan. It employs $48 \%$ of labour force and bestows $60 \%$ to foreign export earnings. Pakistan's current population is almost 210 million which is increasing @ 2.4\% annually. About 67\% of country population lives in the rural areas that depends primarily on agriculture. To meet the needs of human and livestock, crop intensification is being practiced in the country. This resulted into production of more crop residues. Management of crop residues are serious problem in Pakistan. Pakistan is generating 69.5 million tons crop residues per year. It is common practice to burn crop residues especially in Asia [1,2]. Burning causes serious problem to environment by worsening of soil fertility and harms the agricultural land biodiversity [3]. The major adversative effect is greenhouse gases emission that resulted into global warming. So, vermicomposting of crop residues e.g. rice straw, wheat straw protects the environment along with the production of organic fertilizer (vermicompost). This vermicompost improves the soil biodiversity and nutrient status. The consumption of chemical fertilizers in Pakistan is more but yield is considerably low than the developed countries. The overuse of chemical fertilizers leads to increase the environmental pollution through the accumulation of nitrate in drinking water, agricultural products and cadmium accumulation. So, it is need of hours to adopt sustainable agriculture. Vermicomposting is the best alternative to chemical fertilizers. With rise in population, waste management is becoming a serious problem for the community. Pakistan generates 48.5 million tons solid waste per year, which is increasing @ 2\% annually. The composition of solid waste comprises of paper, plastic, rubber, textile waste, animal wastes, leaves, fodder, grass and straws. Mostly, this waste is burned and buried on open lots, threatening the human health and air quality very badly.

Due to lack of waste management infrastructure like other developing countries, it is creating severe environmental problems e.g. smog. Different methods of solid wastes disposal are in use, but these are time consuming and are costly. Therefore, it is the need of hours to adopt cost effective and alternative method of managing solid wastes. In this regard, vermicomposting seems to be a feasible and cost-effective technique for effective management of organic solid wastes [4,5]. Many studies showed the ability of earthworms to consume several types of wastes e.g. animal dung, crop residues, sewage sludge and industrial wastes $[6,7]$. Earthworms split the waste substrate and enhance the decomposition of organic wastes. 
Vermicomposting is bio-oxidative process that leads to the conversion of organic waste to nutrients rich organic fertilizer (vermicompost) through the interaction of earthworms with microorganisms. Vermicomposting significantly alters the physical, chemical and biological properties of wastes. In vermicomposting, only epigeic earthworms can be used. Among these, Eisenia fetida is commonly used in vermicomposting. Vermicompost, the final product of vermicomposting, is nutritious organic fertilizer comprised of nitrogen (2-3\%), potassium (1.85-2.25\%) and phosphorus (1.55-2.25\%), microorganism (nitrogen fixing bacteria, mycorrhizal fungi, zinc and phosphorus solubilizing bacteria and fungi etc.) and marvel growth protectors and promoters [8]. Vermicompost also contains calcium, zinc and manganese along with enzymes such as cellulase, lipase, chitinase and amylase that break down soil organic matter even after excretion from earthworm [9-11] (Table 1).

Table 1: Nutrients composition of cow dung, sheep manure and kitchen waste solid vermicompost [1].

\begin{tabular}{|c|c|c|c|}
\hline $\begin{array}{c}\text { Nutrient } \\
\text { Elements }\end{array}$ & $\begin{array}{c}\text { Cow Dung } \\
\text { Vermicompost }\end{array}$ & $\begin{array}{c}\text { Sheep Manure } \\
\text { Vermicompost }\end{array}$ & $\begin{array}{c}\text { Kitchen Waste } \\
\text { Vermicompost }\end{array}$ \\
\hline Nitrogen (\%) & 1.75 & 1.6 & 1.95 \\
\hline Phosphorus (\%) & 1.01 & 0.41 & 1.73 \\
\hline Potassium (\%) & 0.74 & 0.37 & 1.32 \\
\hline Calcium (\%) & 2.8 & 2.18 & 2.35 \\
\hline Magnesium (\%) & 0.98 & 1.06 & 0.62 \\
\hline Zinc (\%) & 0.04 & 0.04 & 0.045 \\
\hline $\begin{array}{c}\text { Organic matter } \\
(\%)\end{array}$ & 51 & 43 & 41 \\
\hline EC (dS/m) & 6.45 & - & 8.46 \\
\hline
\end{tabular}

\section{Current scenario of vermicomposting in Pakistan}

"Lahore Composting Facility" project is the $1^{\text {st }}$ of its type in Pakistan. It is transferring the composting technology to the country as there are no landfills sites and exposed dumping of waste is practiced. This is first public-private partnership project in Pakistan in area of Municipal Solid Waste Management (MSWM). However, no more research on vermicomposting was conducted in Pakistan. National Agriculture Research Centre (NARC), Islamabad conducted a few studies on vermicomposting. Up till now, no vermicomposting commercial unit was working in the country. Currently, a "Vermicompost Center" has been developed at University of Agriculture Faisalabad, Pakistan by the cooperation of Higher Education Commission of Pakistan (HEC) and researchers from Turkey [12]. This center is working with the objectives of solution-oriented research on vermicomposting, to provide nutritive, cost-effective vermicompost, training of students and farmers to prepare their own vermicompost on their farms.

\section{Future prospective of vermicomposting in Pakistan}

A. Evaluation of vermicompost sector in Pakistan.
B. Provision and production of vermicompost (organic fertilizer) at farmer's own farm.

C. Reduction the dependency on chemical fertilizers and step towards sustainable agriculture for better soil health and productivity.

D. Managing the crop residues effectively and converting them to vermicompost instead of burning that causes smog. So, it is environmentally safe technology.

E. Managing wastes by converting it into organic fertilizer.

F. Bringing more land under cultivation by reducing heavy metals load through vermicomposting.

G. Improving the financial condition of farmers by providing cheap source of fertilizer.

H. Saving capital by reduction of chemical fertilizer imports.

References

1. Gadde B, Bonnet S, Menke C, Garivait S (2000) Air pollutant emissions from rice straw open field burning in India, Thailand and the Philippines. Environ Pollut 157(5): 1554-1558.

2. Mendoza TC, Mendoza BC (2016) A review of sustainability challenges of biomass for energy, focus in the Philippines. Agric Technol 12(2): 281310 .

3. Lohan SK, Jat HS, Yadav AK, Sidhu HS, Jat ML, et al. (2018) Burning issues of paddy residue management in north-west states of India. Renew Sustain Energy Rev 81(1): 693-706.

4. Harris RC, Knox K, Walker N (1990) Strategies for the development of sustainable land fill design. In: IWM Proceeding, pp. 26-29.

5. Logsdson G (1994) Worldwide progress in vermicomposting. Biocycle 35(10): 63-65.

6. Edwards CA (1998) The use of earthworms in the breakdown and management of organic wastes. In: Edwards CA (Ed.), Earthworm Ecol CRC Press, The Netherlands, pp. 327-354.

7. Hartenstein R, Hartenstein F (1981) Physicochemical changes in activated sludge by the earthworm Eisenia foetida. J Environ Qual 10(3): 377-381.

8. Sinha, Rajiv K, Sunil Herat, Gokul Bharambe, Swapnil Patil, Bapat PD, Kunal Chauhan and Valani D (2009) Vermiculture biotechnology: The Emerging cost-effective and sustainable technology of the $21^{\text {st }}$ Century for multiple uses from waste and land management to safe and sustained food production. Environ Res J 3(2/3).

9. Chaoui HI, Zibilske LM, Ohno T (2003) Effects of earthworm's casts and compost on soil microbial activity and plant nutrient availability. Soil Biol Biochem 35(2): 295-302.

10. Lunt HA, Jacobson HG (1994) The chemical composition of earthworm casts. Soil Sci 58(5): 367-376.

11. Tiwari SC, Tiwari BK, Mishra RR (1989) Microbial populations, enzyme activities and nitrogen phosphorus- potassium enrichment in earthworm casts and in surrounding soil of a pineapple plantation. J Biol Fertil Soils 8(2): 178-182.

12. Bellitürk K (2018) Some evaluations about use of vermicompost in agricultural activity of Thrace region, Turkey: A Review. J Rice Res 6(3): 193. 
For possible submissions Click below:

Submit Article 